Brit. J. vener. Dis. (1965), 41, 251.

\title{
IMPORTATION OF SYPHILIS INTO GREAT BRITAIN
}

\section{A BRITISH COOPERATIVE CLINICAL GROUP STUDY*}

Syphilis has traditionally been a disease of seafarers, who through the centuries have been a major factor in the transmission of the disease from one country to another. Few assessments, however, have been made concerning the volume of such importation, especially since air travel has assumed a major role in population movement. Hartmann (1955), in a study of syphilis in Copenhagen, found that $47 \cdot 1$ per cent. of known infections arose directly or indirectly from importation from overseas which could be directly or indirectly traced back to sailors. Of the persons believed likely to be infected, $35 \cdot 1$ per cent. again left the city for an overseas destination. Schofield (1965) reported that, of 502 patients with venereal disease attending the clinics in South Shields and Tynemouth, England, in 1963, 269 (53.6 per cent.) were mariners, of whom 163 (60.6 per cent.) were British and 106 (39.4 per cent.) foreigners; but it was found that few of these patients had syphilis.

Data concerning the importation of venereal disease into the United Kingdom were collected by the Ministry of Health for the first time from the clinics of England and Wales in respect of patients treated in 1963. The findings are summarized in Table I.

TABLE I

IMPORTATION OF VENEREAL DISEASE INTO GREAT BRITAIN IN 1963

Ministry of Health figures

\begin{tabular}{c|c|r|r|r|r}
\hline \multicolumn{1}{c|}{ Disease } & $\begin{array}{r}\text { Total } \\
\text { Cases }\end{array}$ & $\begin{array}{c}\text { Infor- } \\
\text { mation } \\
\text { Available }\end{array}$ & $\begin{array}{r}\text { Im- } \\
\text { ported }\end{array}$ & $\begin{array}{r}\text { Per cent. } \\
\text { Im- } \\
\text { ported } \\
\text { of } \\
\text { Known } \\
\text { Cases }\end{array}$ \\
\hline $\begin{array}{c}\text { Primary and } \\
\text { Secondary } \\
\text { Syphilis }\end{array}$ & $\begin{array}{l}\text { Male } \\
\text { Female }\end{array}$ & 947 & 850 & 218 & $25 \cdot 6$ \\
\cline { 2 - 6 } & Total & 1,129 & 1,013 & 226 & $20 \cdot 0$ \\
\hline Gonorrhoea & Male & 26,833 & 24,826 & 1,642 & $\begin{array}{r}6 \cdot 6 \\
0.8\end{array}$ \\
\cline { 2 - 6 } & Female & 7,916 & 7,348 & 56 & 0.9 \\
\cline { 2 - 6 } & Total & 34,749 & 32,174 & 1,698 & $5 \cdot 3$ \\
\hline
\end{tabular}

* Honorary secretary: R. R. Willcox, M.D., St Mary's Hospital, London, W.2
Importation from outside the United Kingdom was only a small consideration in the epidemiology of gonococcal infections; 6.6 per cent. in males and only 0.8 per cent. in females of the cases for which information was available. For cases of primary and secondary syphilis, on the other hand, importation was much more significant. While in females only 4.9 per cent. of infections for which information was available were imported, in males the figure was no less than $25 \cdot 6$ per cent.

Provisional figures for 1964 show much the same findings (Table II).

TABLE II

IMPORTATION OF VENEREAL DISEASE INTO ENGLAND AND WALES IN 1964 Ministry of Health figures

\begin{tabular}{|c|c|c|c|c|}
\hline \multirow{2}{*}{\multicolumn{2}{|c|}{ Disease }} & \multirow{2}{*}{$\begin{array}{c}\text { Cases for } \\
\text { which } \\
\text { Information } \\
\text { was Available }\end{array}$} & \multicolumn{2}{|c|}{ Cases Imported } \\
\hline & & & No. & Per cent. \\
\hline \multirow{2}{*}{$\begin{array}{l}\text { Primary and } \\
\text { Secondary } \\
\text { Syphilis }\end{array}$} & $\begin{array}{l}\text { Male } \\
\text { Female }\end{array}$ & $\begin{array}{r}1,127 \\
201\end{array}$ & $\begin{array}{r}290 \\
9\end{array}$ & $\begin{array}{r}25 \cdot 7 \\
4 \cdot 5\end{array}$ \\
\hline & Total & 1,328 & 299 & $22 \cdot 5$ \\
\hline \multirow[t]{2}{*}{$\overline{\text { Gonorrhoea }}$} & $\begin{array}{l}\text { Male } \\
\text { Female }\end{array}$ & $\begin{array}{r}27,431 \\
8,187\end{array}$ & $\begin{array}{r}1,736 \\
52\end{array}$ & $\begin{array}{l}6 \cdot 3 \\
0.6\end{array}$ \\
\hline & Total & 35,618 & 1,788 & $5 \cdot 0$ \\
\hline
\end{tabular}

The British Cooperative Clinical Group have recently collected information concerning the country of origin of patients with gonorrhoea and with primary and secondary syphilis, treated in the venereal disease clinics of England and Wales and in Scotland during 1964 . It was decided that information as to importation should also be obtained by race in respect of primary and secondary syphilis with the object of ascertaining which ethnic groups are currently mainly responsible for the imported cases.

\section{Source of Data}

190 clinics in 151 towns and cities in England and Wales and in Scotland participated in the study. During 1964 some 1,066 males and 195 females with primary and secondary syphilis were treated in the 169 clinics in England and Wales, and 91 males and 31 females in the 21 Scottish clinics-an over-all total of 1,383 cases. 


\section{Infections in Males}

Racial Grouping of All Cases.-The racial grouping of the cases in males is shown in Table III.

TABLE III

COUNTRY OF ORIGIN OF ALL MALE PATIENTS IN GREAT BRITAIN

\begin{tabular}{|c|c|c|c|c|c|}
\hline \multirow{2}{*}{\multicolumn{2}{|c|}{ Country of Origin }} & \multicolumn{2}{|c|}{ Scotland } & \multicolumn{2}{|c|}{ England and Wales } \\
\hline & & $\begin{array}{l}\text { No. of } \\
\text { Cases }\end{array}$ & $\begin{array}{c}\text { Per } \\
\text { cent. }\end{array}$ & $\begin{array}{l}\text { No. of } \\
\text { Cases }\end{array}$ & $\begin{array}{c}\text { Per } \\
\text { cent. }\end{array}$ \\
\hline $\begin{array}{l}\text { West Indies (Negro) } \\
\text { Africa (Negro) } \\
\text { Other Negro ... } \\
\text { Asia . . . } \\
\text { Mediterranean } \\
\text { United Kingdom } \\
\text { Eire . . . . } \\
\text { Europe } \\
\text { Other Non-Negro }\end{array}$ & $\begin{array}{l}\text { ) } \\
\cdots \\
\cdots \\
\cdots \\
\cdots \\
\cdots\end{array}$ & $\begin{array}{r}1 \\
2 \\
4 \\
3 \\
68 \\
1 \\
12 \\
-\end{array}$ & $\begin{array}{r}1 \cdot 1 \\
2 \cdot 2 \\
4 \cdot 4 \\
3 \cdot 3 \\
74 \cdot 7 \\
1 \cdot 1 \\
13 \cdot 2 \\
-\end{array}$ & $\begin{array}{r}63 \\
18 \\
5 \\
110 \\
43 \\
646 \\
57 \\
97 \\
27\end{array}$ & $\begin{array}{r}5 \cdot 9 \\
1 \cdot 7 \\
0 \cdot 5 \\
10 \cdot 3 \\
4 \cdot 0 \\
60 \cdot 6 \\
5 \cdot 3 \\
9 \cdot 1 \\
2 \cdot 5\end{array}$ \\
\hline Total & $\ldots$ & 91 & $100 \cdot 0$ & 1,066 & $100 \cdot 0$ \\
\hline
\end{tabular}

In Scotland $74 \cdot 7$ per cent. of infections occurred in persons born in the United Kingdom. The only significant immigrant group was that of continental Europeans with $13 \cdot 2$ per cent. In England and Wales 60.6 per cent. of infections with primary and secondary syphilis occurred in persons born in the United Kingdom. Significant immigrant groups were Asians ( $10 \cdot 3$ per cent.) and Europeans ( $9 \cdot 1$ per cent.), West Indians being responsible for only 5.9 per cent.

Importation by Racial Groups into England and Wales.-The cases in which details of importation are known are shown in Table IV.

TABLE IV

IMPORTATION BY RACIAL GROUPS INTO ENGLAND AND WALES (MALES)

\begin{tabular}{|c|c|c|c|c|c|}
\hline \multirow{2}{*}{\multicolumn{2}{|c|}{ Country of Origin }} & \multirow{2}{*}{$\begin{array}{c}\text { Total } \\
\text { Cases } \\
\text { in Study }\end{array}$} & \multirow{2}{*}{$\begin{array}{l}\text { Details } \\
\text { of } \\
\text { Impor- } \\
\text { tation }\end{array}$} & \multicolumn{2}{|c|}{ Cases Imported } \\
\hline & & & & No. & $\begin{array}{c}\text { Per } \\
\text { cent. }\end{array}$ \\
\hline $\begin{array}{l}\text { West Indies (Negro) } \\
\text { Africa (Negro) } \\
\text { Other Negro } \\
\text { Asia . . . . } \\
\text { Mediterranean } \\
\text { United Kingdom } \\
\text { Eire . . . } \\
\text { Europe } \\
\text { Other Non-Negro }\end{array}$ & $\begin{array}{l}\cdots \\
\cdots \\
\cdots \\
\cdots \\
\cdots \\
\cdots\end{array}$ & $\begin{array}{r}63 \\
18 \\
5 \\
110 \\
43 \\
646 \\
57 \\
97 \\
27\end{array}$ & $\begin{array}{r}55 \\
18 \\
5 \\
106 \\
41 \\
614 \\
56 \\
95 \\
26\end{array}$ & $\begin{array}{r}7 \\
8 \\
2 \\
39 \\
15 \\
127 \\
11 \\
68 \\
13\end{array}$ & $\begin{array}{l}12 \cdot 7 \\
44 \cdot 4 \\
40 \cdot 0 \\
36 \cdot 8 \\
36 \cdot 6 \\
20 \cdot 7 \\
19 \cdot 6 \\
71 \cdot 6 \\
50 \cdot 0\end{array}$ \\
\hline Total & $\ldots$ & 1,066 & 1,016 & 290 & $28 \cdot 5$ \\
\hline
\end{tabular}

Thus, of the 1,066 cases treated in the clinics of England and Wales, details concerning importation were known in 1,016. Of the fifty patients for whom details were unknown, 32 were Europeans, eight West Indians, four Asians, two from the Mediterranean area, two from Europe, one from Eire, and one other non-negro. Of the 1,016 cases in which details were known, 290 were imported $(28 \cdot 5$ per cent.). This figure is a little higher than that for the whole country ( 25.7 per cent.), but the coverage of the male cases in the study was only 90.1 per cent. of the national total and presumably a low percentage of imported infections was encountered in the clinics which failed to report.

The majority of infections occurred in United Kingdom-born persons and of these 20.7 per cent. were imported, with a slightly lower proportion of the much lower total for those born in Eire. High rates of imported infections ( $36 \cdot 6$ to $71 \cdot 6$ per cent.) were obtained for all other immigrant groups (of which Asian and Europeans were numerically the most significant) with the exception of West Indians, in whom only 12.7 per cent. of infections were imported. Using the grouping of West Indians, United Kingdom-born persons, and other immigrants (as employed in other British Co-operative Clinical Group Studies) the data are summarized in Table V.

TABLE V

SUMMARY OF IMPORTATION BY RACIAL GROUPS INTO ENGLAND AND WALES (MALES)

\begin{tabular}{|c|c|c|c|c|}
\hline \multirow{2}{*}{ Race } & \multirow{2}{*}{$\begin{array}{c}\text { Total } \\
\text { Cases } \\
\text { in Study }\end{array}$} & \multirow{2}{*}{$\begin{array}{l}\text { Details of } \\
\text { Impor- } \\
\text { tation } \\
\text { Known }\end{array}$} & \multicolumn{2}{|c|}{ Cases Imported } \\
\hline & & & No. & $\begin{array}{l}\text { Per } \\
\text { cent. }\end{array}$ \\
\hline $\begin{array}{l}\text { West Indians ... } \\
\text { Other Immigrants . . } \\
\text { United Kingdom-born }\end{array}$ & $\begin{array}{r}63 \\
357 \\
646\end{array}$ & $\begin{array}{r}55 \\
347 \\
614\end{array}$ & $\begin{array}{r}7 \\
156 \\
127\end{array}$ & $\begin{array}{l}12 \cdot 7 \\
45 \cdot 0 \\
20 \cdot 7\end{array}$ \\
\hline Total & 1,066 & 1,016 & 290 & $28 \cdot 5$ \\
\hline
\end{tabular}

However the figures are arranged, one fact is crystal clear: that in spite of statements sometimes made to the contrary, the male West Indians are not a significant factor in the importation of syphilis. While responsible for only 5.9 per cent. of the total infections, they contracted $87 \cdot 3$ per cent. of this relatively small number in the United Kingdom.

Importation by Racial Groups into Scotland.-Of 91 cases in the study, details regarding importation were known in 82 (Table VI). Of the nine cases in

TABLE VI

IMPORTATION BY RACIAL GROUPS INTO SCOTLAND (MALES)

\begin{tabular}{|c|c|c|c|c|}
\hline \multirow{2}{*}{ Country of Origin } & \multirow{2}{*}{$\begin{array}{l}\text { Total } \\
\text { Cases in } \\
\text { Study }\end{array}$} & \multirow{2}{*}{$\begin{array}{l}\text { Details of } \\
\text { Impor- } \\
\text { tation } \\
\text { Known }\end{array}$} & \multicolumn{2}{|c|}{ Cases Imported } \\
\hline & & & No. & $\begin{array}{l}\text { Per } \\
\text { cent. }\end{array}$ \\
\hline 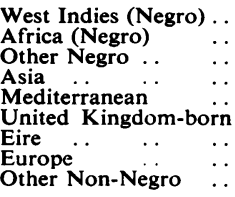 & $\begin{array}{r}1 \\
2 \\
4 \\
3 \\
68 \\
1 \\
12 \\
\end{array}$ & $\begin{array}{r}1 \\
1 \\
3 \\
3 \\
62 \\
1 \\
11 \\
-\end{array}$ & $\begin{array}{r}-1 \\
2 \\
3 \\
24 \\
1 \\
11 \\
-\end{array}$ & $\begin{array}{r}0 \cdot 0 \\
100 \cdot 0 \\
6 \overline{66 \cdot 6} \\
100 \cdot 0 \\
38 \cdot 7 \\
100 \cdot 0 \\
100 \cdot 0 \\
-\end{array}$ \\
\hline Total & 91 & 82 & 42 & $51 \cdot 2$ \\
\hline
\end{tabular}


which these were unknown, six occurred in persons born in the United Kingdom and one each in Africans, Asians, and Europeans. Of the 82 cases for which information was known, no less than $42(51 \cdot 2$ per cent.) were imported-an appreciably higher figure than that for England and Wales.

In those born in the United Kingdom, 38.7 per cent. of infections were imported, whereas of twenty infections in those born outside the United Kingdom no less than eighteen ( 90 per cent.) were imported.

Country of Origin of Those importing Primary and Secondary Syphilis. - The imported cases alone are considered in Table VII.

TABLE VII

RACE OF ALL MALES IMPORTING PRIMARY AND SECONDARY SYPHILIS INTO GREAT BRITAIN

\begin{tabular}{|c|c|c|c|c|c|}
\hline \multirow{2}{*}{\multicolumn{2}{|c|}{ Country of Origin }} & \multicolumn{2}{|c|}{ Scotland } & \multicolumn{2}{|c|}{ England and Wales } \\
\hline & & $\begin{array}{l}\text { No. of } \\
\text { Cases }\end{array}$ & $\begin{array}{c}\text { Per } \\
\text { cent. }\end{array}$ & $\begin{array}{l}\text { No. of } \\
\text { Cases }\end{array}$ & $\begin{array}{c}\text { Per } \\
\text { cent. }\end{array}$ \\
\hline $\begin{array}{l}\text { West Indies (Negro) } \\
\text { Africa (Negro) } \\
\text { Other Negro ... } \\
\text { Asia .. } \\
\text { Mediterranean } \\
\text { United Kingdom } \\
\text { Eire .. } \\
\text { Europe } \quad . \\
\text { Other Non-Negro }\end{array}$ & $\begin{array}{l}\ldots \\
\because \\
\therefore \\
\therefore \\
\cdots \\
\cdots\end{array}$ & $\begin{array}{r}-\overline{1} \\
2 \\
3 \\
24 \\
1 \\
11 \\
-\end{array}$ & $\begin{array}{r}2 \overline{2 \cdot 4} \\
\overline{4 \cdot 8} \\
7 \cdot 1 \\
57 \cdot 1 \\
2 \cdot 4 \\
26 \cdot 2 \\
-\end{array}$ & $\begin{array}{r}7 \\
8 \\
2 \\
39 \\
15 \\
127 \\
11 \\
68 \\
13\end{array}$ & $\begin{array}{r}2 \cdot 4 \\
2 \cdot 8 \\
0.7 \\
13 \cdot 4 \\
5 \cdot 2 \\
43 \cdot 8 \\
3 \cdot 8 \\
23 \cdot 4 \\
4 \cdot 5\end{array}$ \\
\hline Total & $\ldots$ & 42 & & 290 & $100 \cdot 0$ \\
\hline
\end{tabular}

In England and Wales, even of the imported infections, 43.8 per cent. were introduced by those born in the United Kingdom and 23.4 per cent. by Europeans. The third most important group was that of the Asians (13.4 per cent.). The West Indians were low on the list, only 2.4 per cent. of imported infections occurring in this group. In Scotland, too, the highest proportion of imported infections $(57 \cdot 1$ per cent.) was introduced by persons born in the United Kingdom and second were Europeans, who accounted for $26 \cdot 2$ per cent.

Country of Origin of Those acquiring Primary and Secondary Syphilis in the United Kingdom.-The cases of primary and secondary syphilis which were not imported are considered in Table VIII. Not surprisingly, most of the infections with primary and secondary syphilis acquired in England and Wales were contracted by United Kingdom-born persons (67.1 per cent.). Nevertheless, 32.9 per cent. of home-acquired infections were acquired by immigrants, the most important being the Asians $(9 \cdot 2$ per cent.), the West Indians (6.6 per cent.), and the Irish $(6 \cdot 2$ per cent.). In Scotland, 95 per cent. of the infections acquired affected United Kingdom-born persons. How many of these infections arising within the United Kingdom were indirectly related to imported cases is not known.

TABLE VIII

COUNTRY OF ORIGIN OF MALES ACQUIRING SYPHILIS IN GREAT BRITAIN

\begin{tabular}{|c|c|c|c|}
\hline \multirow{2}{*}{ Country of Origin } & \multirow{2}{*}{ Scotland } & \multicolumn{2}{|c|}{ England and Wales } \\
\hline & & No. of Cases & Per cent. \\
\hline 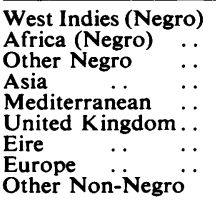 & $\frac{1}{\frac{1}{1}}$ & $\begin{array}{r}48 \\
10 \\
3 \\
67 \\
26 \\
487 \\
45 \\
27 \\
13\end{array}$ & $\begin{array}{r}6 \cdot 6 \\
1 \cdot 4 \\
0 \cdot 4 \\
9 \cdot 2 \\
3 \cdot 6 \\
67 \cdot 1 \\
6 \cdot 2 \\
3 \cdot 7 \\
1 \cdot 8\end{array}$ \\
\hline Total $\ldots$ & 40 & 726 & $100 \cdot 0$ \\
\hline
\end{tabular}

Infections seen in Port and Other Clinics

An attempt has been made to indicate how much imported syphilis is seen in sea ports and how much in other areas. Some difficulty is experienced in the grouping of clinics. Few problems are encountered in respect of the smaller ports which can readily be classified as ports or otherwise. With the larger cities (i.e. London, Glasgow, Edinburgh, Manchester, Bristol), however, there are greater difficulties. Obviously the port activities form but a part of the whole life of these great centres, and the relatively low level of importation-especially in Londonwhich is noted if these cities as a whole are grouped as "ports" bears this out. On the other hand, if only the port clinics in these cities are considered, maritime personnel who import infections into other clinics in the same cities will influence unfairly the figures of the towns and cities other than ports. Of the two alternatives, it was decided to include as port clinics single clinics in smaller ports and seamen's clinics in the large cities and to classify other clinics in the large cities as other than port clinics.

\section{Distribution of Port Clinics}

The distribution of port and other clinics as adopted in the study is shown in Table IX(overleaf).

Total Cases of Primary and Secondary Syphilis in Port and Other Clinics

Table X (overleaf) shows that 24.4 per cent. of the total infections with primary and secondary syphilis, both imported and not imported, were treated in the 31 port clinics in England and Wales whereas 75.6 per cent. were treated in the 138 other clinics. In all, 260 cases were treated in 31 port clinics (an average 8.4 cases per port clinic) compared with 806 cases in the 138 other clinics (average $5 \cdot 8$ cases per clinic). 
TABLE IX

DISTRIBUTION OF 190 PORT AND OTHER CLINICS

\begin{tabular}{|c|c|c|c|c|c|c|c|c|}
\hline \multicolumn{5}{|c|}{ Area } & $\begin{array}{l}\text { No. of Towns } \\
\text { or Cities }\end{array}$ & Port Clinics ${ }^{1}$ & Other Clinics & Total Clinics \\
\hline \multirow[t]{2}{*}{ England and Wales } & $\begin{array}{l}\text { Londo } \\
500,000 \\
100,000 \\
50,000 \\
\text { Under }\end{array}$ & $\begin{array}{l}\text { More } \\
0,000 \\
000 \\
000\end{array}$ & $\begin{array}{l}\cdots \\
\cdots \\
\cdots \\
\cdots\end{array}$ & $\begin{array}{l}\ldots \\
\ldots \\
\ldots \\
\ldots\end{array}$ & $\begin{array}{r}1 \\
4 \\
38 \\
47 \\
46 \\
\end{array}$ & $\begin{array}{r}2^{2} \\
2^{3} \\
14^{4} \\
5^{5} \\
8^{6}\end{array}$ & $\begin{array}{r}22 \\
7 \\
29 \\
42 \\
38\end{array}$ & $\begin{array}{r}24 \\
9 \\
43 \\
47 \\
46\end{array}$ \\
\hline & Total & . & $\ldots$ & . & 136 & 31 & 138 & 169 \\
\hline Scotland & . & $\ldots$ & $\ldots$ & $\ldots$ & 15 & $6^{7}$ & 15 & 21 \\
\hline
\end{tabular}

1 Port clinics only in major cities or single clinics in ports.

Albert Dock; Seamen's Hospital Greenwich.

4 Avonmouth, Birkenhead, Cardiff, Ipswich, Hull, Middlesbrough, Newcastle, Newport (Mon.), Portsmouth, Plymouth, Southampton, South Shields, Sunderland, Swansea.

5 Barrow*, Gravesend, North Shields, Port Talbot*, West Hartlepool*.

6 Barnstaple, Barry*, Dover, Falmouth, Goole, Tilbury, Whitehaven*, Workington*.

? Aberdeen, Dundee, Falkirk (Grangemouth), Glasgow (Broomielaw only), Greenock, Leith.

* These clinics gave nil returns.

TABLE $X$

DISTRIBUTION OF TOTAL CASES IN PORT AND OTHER CLINICS

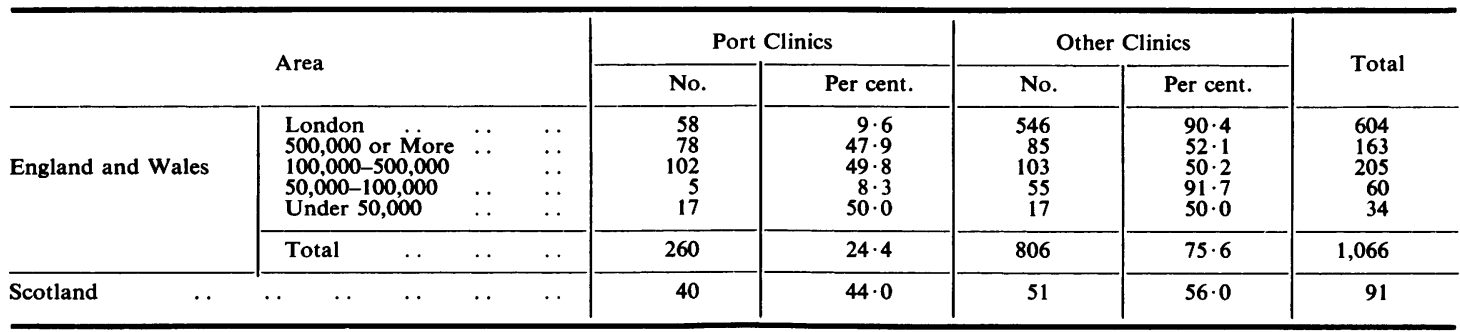

In Scotland 44.0 per cent. of the total numioer of infections were treated in the port clinics.

\section{Distribution of Cases for which Details of Importation are Known in Clinics}

Details of importation were known in respect of 96.5 per cent. of patients attending port clinics in England and Wales and 95 per cent. in Scotland; for the other clinics the figures were 94.9 and 87.5 per cent. respectively (Table XI).

\section{Distribution of Imported Cases of Primary and Secondary Syphilis by Port and Other Clinics}

In all clinics the percentage of imported cases was notably higher (33.3-59.4 per cent.) in areas in England and Wales outside London and also in Scotland than in London itself where only $17 \cdot 8$ per cent. of male infections were imported (Table XII, opposite).

In the port clinics of all areas the vast majority of cases $(72 \cdot 5$ per cent. in England and Wales and $65 \cdot 8$
TABLE XI

DISTRIBUTION BY PORT AND OTHER CLINICS OF CASES FOR WHICH DETAILS OF IMPORTATION ARE KNOWN

\begin{tabular}{|c|c|c|c|c|}
\hline & Area & $\begin{array}{l}\text { Port } \\
\text { Clinics }\end{array}$ & $\begin{array}{l}\text { Other } \\
\text { Clinics }\end{array}$ & Tota \\
\hline \multirow[t]{3}{*}{$\begin{array}{l}\text { England } \\
\text { and } \\
\text { Wales }\end{array}$} & $\begin{array}{l}\text { London } . \\
500,000 \text { or more } \\
100,000-500,000 \\
50,000-100,000 \\
\text { Under } 50,000 \ldots\end{array}$ & $\begin{array}{r}56 \\
75 \\
98 \\
5 \\
17\end{array}$ & $\begin{array}{r}528 \\
85 \\
88 \\
49 \\
15\end{array}$ & $\begin{array}{r}584 \\
160 \\
186 \\
54 \\
32\end{array}$ \\
\hline & $\begin{array}{l}\text { Total Known } \\
\text { Total in Survey }\end{array}$ & $\begin{array}{l}251 \\
260\end{array}$ & $\begin{array}{l}765 \\
806\end{array}$ & $\begin{array}{l}1,016 \\
1,066\end{array}$ \\
\hline & Percentage Known & $96 \cdot 5$ & $94 \cdot 9$ & $95 \cdot 3$ \\
\hline \multirow[t]{2}{*}{ Scotland } & $\begin{array}{l}\text { Total Known } \\
\text { Total in Survey }\end{array}$ & $\begin{array}{l}38 \\
40\end{array}$ & $\begin{array}{l}44 \\
51\end{array}$ & $\begin{array}{l}82 \\
91\end{array}$ \\
\hline & Percentage Known & $95 \cdot 0$ & $87 \cdot 5$ & $90 \cdot 1$ \\
\hline
\end{tabular}

per cent. in Scotland) were imported. In the other clinics of England and Wales, however, only $14 \cdot 1$ per cent. were imported, the proportion being significantly lower in London and cities exceeding 500,000 population. A much higher proportion of imported cases was included in the smaller numbers 
TABLE XII

DISTRIBUTION OF IMPORTED CASES IN CLINICS

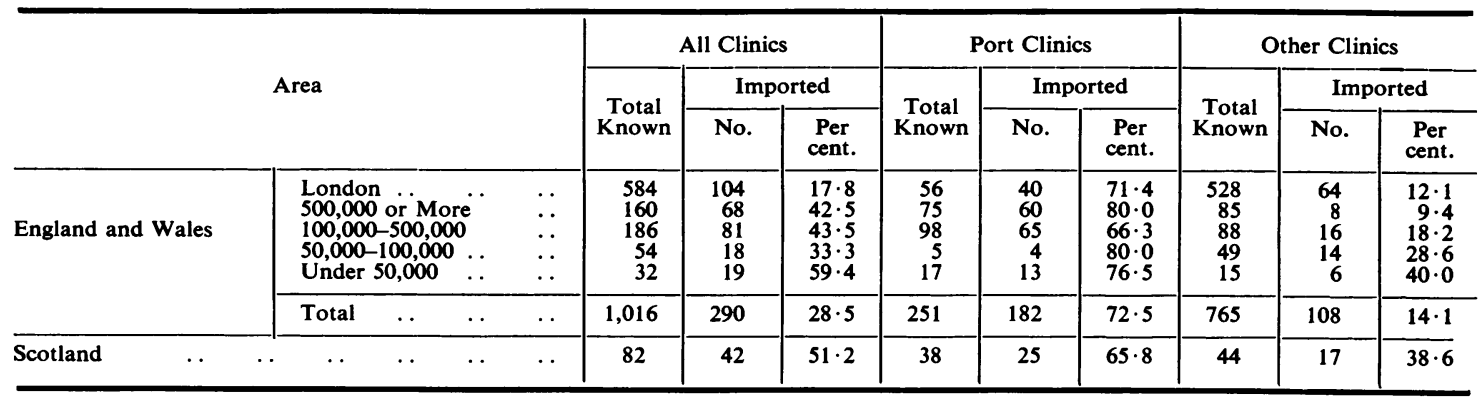

of cases treated in non-port towns and cities of populations below 100,000 and in Scotlandprobably reflecting the influence of air travel.

The importation of cases in port and other clinics is summarized in Table XIII.
Country of Origin of Imported Cases in Port and Other Clinics

Table XIV shows that in England and Wales $62 \cdot 8$ per cent. of the imported infections were treated in the 31 port clinics and only 37.2 per cent. in the remaining 138 clinics. The figure for United King-

TABLE XIII

SUMMARY OF IMPORTED CASES IN PORT AND OTHER CLINICS

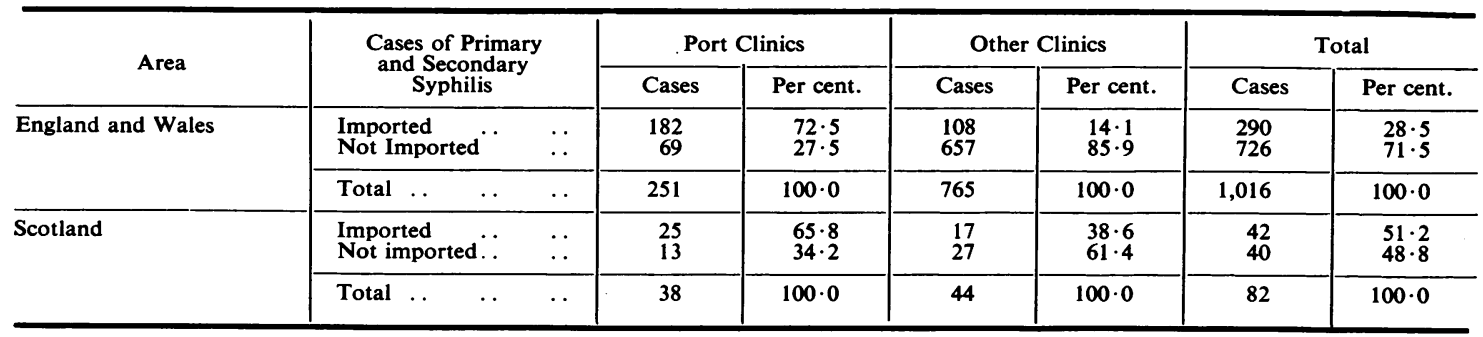

TABLE XIV

COUNTRY OF ORIGIN OF IMPORTED CASES IN PORT AND OTHER CLINICS

\begin{tabular}{|c|c|c|c|c|c|c|c|c|}
\hline \multirow{2}{*}{ Area } & \multirow{2}{*}{\multicolumn{2}{|c|}{ Country of Origin }} & \multicolumn{2}{|c|}{ Port Clinics } & \multicolumn{2}{|c|}{ Other Clinics } & \multicolumn{2}{|c|}{ Total } \\
\hline & & & Cases & Per cent. & Cases & Per cent. & Cases & Per cent. \\
\hline \multirow[t]{2}{*}{ England and Wales } & $\begin{array}{l}\text { West Indies (Negro) } \\
\text { Africa (Negro) } \\
\text { Other Negro }\end{array}$ & $\begin{array}{l}\cdots \\
\cdots \\
\cdots \\
\cdots \\
\cdots \\
\cdots \\
\cdots\end{array}$ & $\begin{array}{r}5 \\
5 \\
1 \\
32 \\
13 \\
70 \\
6 \\
43 \\
7\end{array}$ & $\begin{array}{l}71 \cdot 5 \\
62 \cdot 5 \\
50 \cdot 0 \\
82 \cdot 1 \\
86 \cdot 7 \\
55 \cdot 1 \\
54 \cdot 5 \\
63 \cdot 2 \\
53 \cdot 8\end{array}$ & $\begin{array}{r}2 \\
3 \\
1 \\
7 \\
2 \\
57 \\
5 \\
25 \\
6\end{array}$ & $\begin{array}{l}28 \cdot 5 \\
37 \cdot 5 \\
50 \cdot 0 \\
17 \cdot 9 \\
13 \cdot 3 \\
44 \cdot 9 \\
45 \cdot 5 \\
36 \cdot 8 \\
46 \cdot 2\end{array}$ & $\begin{array}{r}7 \\
8 \\
2 \\
39 \\
15 \\
127 \\
11 \\
68 \\
13\end{array}$ & $\begin{array}{l}100 \cdot 0 \\
100 \cdot 0 \\
100 \cdot 0 \\
100 \cdot 0 \\
100 \cdot 0 \\
100 \cdot 0 \\
100 \cdot 0 \\
100 \cdot 0 \\
100 \cdot 0\end{array}$ \\
\hline & Total & $\ldots$ & 182 & $62 \cdot 8$ & 108 & $37 \cdot 2$ & 290 & $100 \cdot 0$ \\
\hline \multirow[t]{2}{*}{ Scotland } & $\begin{array}{l}\text { West Indies (Negro) } \\
\text { Africa (Negro) } \\
\text { Other Negro } \\
\text { Asia.. } \\
\text { Mediterranean } \\
\text { United Kingdom }\end{array}$ & $\begin{array}{l}\cdots \\
\cdots \\
\cdots \\
\cdots \\
\cdots \\
\cdots \\
\cdots\end{array}$ & $\begin{array}{r}\frac{1}{2} \\
\frac{2}{11} \\
\frac{9}{-}\end{array}$ & $\begin{array}{c}100 \cdot 0 \\
\overline{100 \cdot 0} \\
66 \cdot 6 \\
45 \cdot 8 \\
\overline{81 \cdot 8} \\
-\end{array}$ & $\begin{array}{l}- \\
\bar{E} \\
\overline{1} \\
13 \\
1 \\
2 \\
-\end{array}$ & $\begin{array}{c}- \\
- \\
\bar{Z} \\
33 \cdot 3 \\
54 \cdot 2 \\
100 \cdot 0 \\
18 \cdot 2 \\
-\end{array}$ & $\begin{array}{r}-1 \\
2 \\
3 \\
24 \\
1 \\
11 \\
-\end{array}$ & $\begin{array}{c}100 \cdot 0 \\
100 \cdot 0 \\
100 \cdot 0 \\
100 \cdot 0 \\
100 \cdot 0 \\
100 \cdot 0 \\
-\end{array}$ \\
\hline & Total & $\ldots$ & 25 & $59 \cdot 5$ & 17 & $40 \cdot 5$ & 42 & $100 \cdot 0$ \\
\hline
\end{tabular}


dom-born persons treated in the port clinics was $55 \cdot 1$ per cent., for Europeans $63 \cdot 2$ per cent., and for Asians no less than $82 \cdot 1$ per cent.

In Scotland 59.5 per cent. of the imported infections were treated in the port clinics. The proportion was lowest for those born in the United Kingdom, of whom 45.8 per cent. were treated in the six port clinics and $54 \cdot 2$ per cent. in the fifteen other clinics, but of the small total number of eighteen immigrants importing infectious syphilis into Scotland no less than fourteen ( 77.8 per cent.) were treated in the port clinics.

\section{Race}

\section{Details of Precise Site of Importation}

Complete details by race are shown in the Annex. There are three main racial groups:

(1) Those born in the United Kingdom;

(2) Europeans, Irish, and other Non-Negroes;

(3) Other immigrants.

The findings are summarized in Table XV.

TABLE XV

CASES IMPORTED INTO ENGLAND AND WALES AND SCOTLAND BY RACE

\begin{tabular}{|c|c|c|c|c|}
\hline Race & Total & $\begin{array}{c}\text { Port } \\
\text { Clinics }\end{array}$ & $\begin{array}{l}\text { Other } \\
\text { Clinics }\end{array}$ & $\begin{array}{l}\text { Per } \\
\text { cent. in } \\
\text { Port } \\
\text { Clinics }\end{array}$ \\
\hline $\begin{array}{l}\text { United Kingdom-born } \\
\text { Europeans, Irish, and Other }\end{array}$ & 151 & 81 & 70 & $53 \cdot 6$ \\
\hline $\begin{array}{cc}\text { Non-Negroes } \\
\text { Other Immigrants }\end{array} .$. & $\begin{array}{r}104 \\
77\end{array}$ & $\begin{array}{l}65 \\
61\end{array}$ & $\begin{array}{l}39 \\
16\end{array}$ & $\begin{array}{l}62 \cdot 5 \\
79 \cdot 1\end{array}$ \\
\hline $\begin{array}{lll}\text { Total } & \ldots & \ldots\end{array}$ & 332 & 207 & 125 & $60 \cdot 4$ \\
\hline
\end{tabular}

Of the other immigrants importing syphilis no less than 79.1 per cent. were encountered in the port clinics. For the Europeans, Irish, and other nonnegroes the figure was less $(62.5$ per cent.) while of the United Kingdom-born persons importing syphilis only 53.6 per cent. were seen in the port clinics-but even so this figure is more than half the total.

\section{Clinics of Entry}

In most clinics the number of imported infections were very few, often one or two or at best a mere handful each year. The clinics in which more than ten imported infections were noted in the year are listed in Table XVI.

By far the greatest number of imported cases was seen at the Seamen's Dispensary, Liverpool. Five of the eight clinics were port clinics and three (all in London) were not. In all, 168 of the 290 imported infections in England and Wales (57.9 per cent.) were treated in these eight clinics, $82(28 \cdot 2$ per cent.) being treated in the five London clinics listed in the
TABLE XVI

EIGHT CLINICS IMPORTING MORE THAN TEN CASES PER YEAR

\begin{tabular}{|c|c|c|c|c|}
\hline \multirow{2}{*}{ Clinic } & \multirow{2}{*}{$\begin{array}{l}\text { Total } \\
\text { Cases }\end{array}$} & \multirow{2}{*}{$\begin{array}{c}\text { Details of } \\
\text { Importation } \\
\text { Known }\end{array}$} & \multicolumn{2}{|c|}{ Cases Imported } \\
\hline & & & No. & $\begin{array}{c}\text { Per } \\
\text { cent. }\end{array}$ \\
\hline 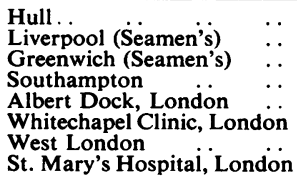 & $\begin{array}{r}15 \\
75 \\
38 \\
21 \\
20 \\
74 \\
81 \\
128\end{array}$ & $\begin{array}{r}15 \\
72 \\
36 \\
21 \\
20 \\
64 \\
81 \\
128\end{array}$ & $\begin{array}{l}14 \\
58 \\
27 \\
14 \\
13 \\
15 \\
12 \\
15\end{array}$ & $\begin{array}{l}93 \cdot 3 \\
80 \cdot 1 \\
75 \cdot 0 \\
66 \cdot 6 \\
65 \cdot 0 \\
21 \cdot 9 \\
14 \cdot 8 \\
11 \cdot 7\end{array}$ \\
\hline Total & 452 & 437 & 168 & $38 \cdot 4$ \\
\hline
\end{tabular}

Table. No single Scottish clinic qualified for inclusion in the Table.

It is probable that seamen with primary and secondary syphilis seen in a port clinic (who usually attend soon after arrival and are promptly treated) represent a much smaller epidemiological problem than those with infections imported into other areas which generally become more widely disseminated throughout the community.

\section{Infections in Females}

Females offer no problem in the importation of syphilis. Of the total of 195 cases treated in the clinics of England and Wales, details of importation were known in respect of 177 . Only six infections $(3 \cdot 4$ per cent.) were imported (two in United Kingdomborn persons, two in Europeans, and two in other groups). Only one case was seen at a port clinic.

In Scotland information regarding importation was known in 30 of the 31 infections and none was imported (Table XVII, opposite).

No information is available as to how many infections in females were related to imported infections in males.

Increased air travel has apparently hitherto not led to any significant importation of syphilis by United Kingdom-born females.

\section{Summary and Conclusions}

(1) Data concerning the importation of syphilis are provided from 190 clinics in 151 towns and cities in England and Wales and in Scotland. 1,066 cases in males were treated in the clinics of England and Wales, details regarding importation being known in 1,016, and 91 cases were treated in Scotland, details regarding importation being known in 82 .

(2) 290 cases in males in England and Wales (28.5 per cent. of known cases) were imported and 42 in Scotland (51.2 per cent.). 
TABLE XVII

IMPORTATION OF PRIMARY AND SECONDARY SYPHILIS INTO GREAT BRITAIN BY FEMALES

\begin{tabular}{|c|c|c|c|c|c|c|}
\hline \multirow{2}{*}{ Area } & \multirow{2}{*}{\multicolumn{2}{|c|}{ Country of Origin }} & \multirow{2}{*}{ Total Cases } & \multirow{2}{*}{ Total Known } & \multicolumn{2}{|c|}{ Cases Imported } \\
\hline & & & & & No. & Per cent. \\
\hline \multirow[t]{2}{*}{ England and Wales } & $\begin{array}{l}\text { West Indies (Negro } \\
\text { Africa (Negro) } \\
\text { Other Negro } \\
\text { Asia.. } \\
\text { Mediterranean } \\
\text { United Kingdom } \\
\text { Eire.. } \\
\text { Europe .. } \\
\text { Other Non-Negro. }\end{array}$ & $\begin{array}{l}\cdots \\
\cdots \\
\cdots \\
\cdots \\
\cdots \\
\cdots \\
\cdots\end{array}$ & $\begin{array}{r}19 \\
1 \\
2 \\
2 \\
154 \\
8 \\
9 \\
-\end{array}$ & $\begin{array}{r}18 \\
1 \\
2 \\
2 \\
137 \\
8 \\
9 \\
-\end{array}$ & $\frac{1}{-}$ & $\begin{array}{c}5 \cdot 6 \\
100 \cdot 0 \\
\overline{-} \\
\overline{1 \cdot 5} \\
22 \cdot 2 \\
-\end{array}$ \\
\hline & Total & $\ldots$ & 195 & 177 & 6 & $3 \cdot 4$ \\
\hline \multirow[t]{2}{*}{ Scotland } & $\begin{array}{l}\text { United Kingdom } \\
\text { Eire.. }\end{array}$ & 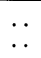 & $\begin{array}{r}30 \\
1\end{array}$ & $\begin{array}{r}29 \\
1\end{array}$ & - & - \\
\hline & Total & $\cdots$ & 31 & 30 & - & - \\
\hline
\end{tabular}

(3) Of the infections in males imported into England and Wales, no less than 43.8 per cent. occurred in men born in the United Kingdom. Europeans formed the second largest group (23.4 per cent.), with Asians third (13.4 per cent.). West Indians, with only seven imported cases, accounted for only $2 \cdot 4$ per cent. and this group was the smallest when imported infections were assessed as a percentage of total infections in each racial group. The West Indian male is not therefore a significant factor in the importation of syphilis into the British Isles.

(4) Of infections contracted within the United Kingdom, persons born in the United Kingdom accounted for $67 \cdot 1$ per cent. Asians were second $(9 \cdot 2$ per cent.), West Indians third ( 6.6 per cent.) and Irish fourth $(6 \cdot 2$ per cent.). How many of these infections were indirectly related to imported cases is not known.

(5) The clinics were grouped not only by the size of the town or city in which they were situated, but also into 37 port clinics and 153 other clinics, "port clinics" being special Seamen's clinics in major cities or single clinics in ports. In the port clinics of England and Wales, $72 \cdot 5$ per cent. of infections were imported, while in the other clinics only $14 \cdot 1$ per cent. were imported. The comparable figures for Scotland were $65 \cdot 8$ and $38 \cdot 6$ per cent.

In England and Wales $62 \cdot 8$ per cent. of the imported infections were treated in 31 port clinics and $37 \cdot 2$ per cent. in 138 other clinics. The comparable Scottish figures were 59.5 per cent. for six port clinics and $\mathbf{4 0} \cdot \mathbf{5}$ per cent. for fifteen other clinics.
(6) In England and Wales and in Scotland, in West Indian, African, other Negro, Asian, and Mediterranean immigrants, no less than $79 \cdot 1$ per cent. of imported infections were seen in the port clinics. In Europeans, Irish, and other non-Negroes, the figure was $62 \cdot 5$ per cent., while of United Kingdom-born persons only 53.6 per cent. were seen in port clinics.

(7) The seaport would appear to remain the major channel for the importation of syphilis. Eight clinics are listed (five major port clinics and five situated in London) in which 57.9 per cent. of imported infections were seen. The largest single port of entry was the Seamen's Dispensary, Liverpool, with 58 imported cases, but a total of 82 imported cases were treated in five London clinics, only two of which were listed as port clinics.

(8) Females offer no problem in relation to the importation of syphilis. In England and Wales details of importation were known for 177 cases, but only in six ( 3.4 per cent.) were the infections imported.

In Scotland information was available for thirty of 31 cases seen, and none was imported.

No information is available as to how many infections in females were related to imported infections in males.

\section{ANNEX \\ DETAILS OF IMPORTED CASES Males}

West Indian Negroes: Only seven cases were imported -five into port clinics (Albert Dock 2, Gravesend 2, Greenwich 1) and two into Gloucester. The bulk of even this small number could probably be in seamen.

None was imported into Scotland. 
African Negroes: Of the eight cases, one was seen in each of five port clinics (Albert Dock, Hull, Newcastle, Newport (Mon.), Tilbury) and one each in the non-port clinics of Liverpool (Bootle), Uxbridge, and West London.

One was imported into the port clinic at Glasgow (Broomielaw).

Other Negroes: Two cases only, one at Seamen's Dispensary, Liverpool, and one at St. Mary's, London. None was imported into Scotland.

Asians: This was the third largest group (39 cases); 32 were treated in port clinics (Seamen's Hospital, Greenwich 8, Seamen's Dispensary, Liverpool 8, Albert Dock 4, Southampton 4, Tilbury 4, Hull 2, Newcastle 1, Plymouth 1), and seven in other clinics (two each at West London and Liverpool (Bootle), and one each at Brighton, Uxbridge, and the Whitechapel Clinic.

Two were imported into port clinics in Scotland (Greenock 1, Glasgow (Broomielaw) 1).

Mediterranean: Of the fifteen patients, thirteen were treated in port clinics (6 at Seamen's Dispensary Liverpool, 2 at Avonmouth, and one each at Middlesbrough, Seamen's Hospital Greenwich, Plymouth, Southampton, Tilbury) and two in other clinics (St. Helier and West London).

Three cases were imported into Scotland, two into the port clinics at Falkirk (Grangemouth) and Glasgow (Broomielaw) and one into Dunfermline.

United Kingdom: This was by far the largest group. No less than 127 cases were imported by United Kingdomborn persons into England and Wales. Seventy cases were seen in the port clinics (Seamen's Dispensary, Liverpool 22. Seamen's Hospital, Greenwich 9, Southampton 9, Newcastle 5, Hull 4, Albert Dock 3, Cardiff 3, Portsmouth 2, North Shields 2, South Shields 2, Sunderland 2, Avonmouth 1, Dover 1, Ipswich, 1, Middlesbrough 1, Newport (Mon.) 1, Tilbury 1, Swansea 1.)

Of the 57 cases seen in other clinics, 32 were seen in nine London clinics (Whitechapel Clinic 9, Endell St. 6, St. Mary's 5, West London 4, Queen Mary's, Stratford 3, Guy's 2, St. Helier 1, St. Thomas's 1, Royal Free 1), three each in Manchester (St. Luke's) and Uxbridge, two in Bristol, and one each in Aldershot, Bournemouth, Brighton, Canterbury, Darlington, Exeter, Leeds, Lincoln, Liverpool (Royal Infirmary), Maidstone, Norwich, Nottingham, Reading, Sheffield, Torquay, Truro, and Wolverhampton.

Of 24 cases imported into Scotland eleven were seen in port clinics (Aberdeen 4, Glasgow (Broomielaw) 3, Leith 2, Falkirk (Grangemouth) 2), and thirteen in other clinics (Edinburgh 7, other Glasgow clinics 2, Paisley 2, Ayr 1, Hamilton 1).

Eire: Only eleven infections were imported by men from Southern Ireland. Six were seen at port clinics (Seamen's Dispensary, Liverpool 4, Seamen's Hospital, Greenwich 1, Swansea 1) and five in four London clinics (St. Mary's 2, Royal Northern 1, St. Mary's 1, and West London 1).

One was treated in Scotland in Glasgow, not in the port clinic.
Europe: This was the second largest group, with 68 cases, 43 were seen in the port clinics (Seamen's dispensary, Liverpool 15, Hull 6, Seamen's Hospital, Greenwich 5, Newport (Mon.) 5, Tilbury 3, Albert Dock 2, Seamen's Dispensary, Manchester 2, Swansea 2, Falmouth 1, Goole 1, Newcastle 1).

25 were seen at non-port clinics, fourteen of them in London clinics (St. Mary's 4, Whitechapel Clinic 3, St. Thomas's 3, West London 3, Royal Northern 1), four at Preston, 2 each at Blackpool and St. Austell, and one each at Carlisle, Watford, and Windsor.

Of eleven cases imported into Scotland, nine were seen in port clinics (Falkirk (Grangemouth) 6, Aberdeen 2, Dundee 1) and two in other clinics (Dunfermline and Paisley).

Other Non-Negro: Of thirteen cases, seven were seen in the port clinics (Seamen's Dispensary, Liverpool 2, Seamen's Hospital, Greenwich 2, Birkenhead 1, Hull 1, Albert Dock 1). Six others were treated in four London clinics (St. Mary's 3, St Barts 1, Guy's 1, and Whitechapel Clinic 1).

None was treated in Scotland.

\section{Females}

One female West Indian imported infection through Gravesend, one African female through St. Mary's, two United Kingdom-born females through Coventry and St. Mary's, and two Europeans through Exeter and St. Mary's.

\section{NOTE}

The clinics concerned are listed in the 1964 British Cooperative Clinical Group Gonorrhoea Study. (Brit.J. vener. Dis. (1965),41,242).

\section{Importation de la syphilis en Grande Bretagne \\ RÉSUMÉ}

(1) Les faits concernant l'importation de la syphilis sont fournis par 190 dispensaires de 151 villes d'Angleterre, du pays de Galles et de l'Écosse. De 1.066 hommes soignés dans les dispensaires d'Angleterre et du pays de Galles, 1.016 donnèrent des précisions sur la provenance de leur syphilis. L'origine de la syphilis fut également connue dans 82 des 91 cas traités en Écosse.

(2) La syphilis fut importée chez 290 mâles d'Angleterre et du pays de Galles (soit $28,5 \%$ des cas connus), et chez 42 mâles d'Écosse (51,2\% des cas).

(3) Pas moins de 43,8\% des cas de syphilis mâles importés furent trouvés chez ceux nés au Royaume-Uni. Les européens furent seconde $(23,4 \%)$ et les asiatiques troisième $(13,4 \%)$. Les antillais, avec seulement 7 cas importés, répresentèrent $2,4 \%$ des cas : ce groupe fut le plus petit lorsqu'on établit pour chaque race le pourcentage des cas importés par rapport au taux des infections syphilitiques. On peut en conclure que l'antillais ne constitue pas un facteur d'importation notoire de la syphilis dans les îles britanniques. 
(4) Pour ce qui est des infections contractées au Royaume-Uni, $67,1 \%$ des cas furent répresentés par les natifs de ce pays suivis par les asiatiques $(9,2 \%)$, les antillais $(6,6 \%)$, et les irlandais $(6,2 \%)$. On ne sait pas combien de ces infections furent la conséquence indirecte des infections importées.

(5) Les dispensaires furent groupés non seulement d'après la population des villes ou ils étaient situés, mais aussi en 37 dispensaires de ports et 153 autres dispensaires. On appelle "dispensaires de port" ceux réservés aux marins dans les grandes cités et les dispensaires ordinaires des ports. Dans les dispensaires de port en Angleterre et au pays de Galles, $72,5 \%$ des infections furent importées par contre à $14,1 \%$ aux autres cliniques. Les chiffres correspondants pour l'Écosse furent $65,8 \%$ et $38,6 \%$. En Angleterre et au pays de Galles on traita $62,8 \%$ des infections importées dans 31 dispensaires de port et $37,2 \%$ dans 138 autres dispensaires. Les chiffres correspondants pour l'Écosse furent $59,5 \%$ pour 6 dispensaires de port et $40,5 \%$ pour 15 dispensaires ordinaires.

(6) En Angleterre, au pays de Galles, et en Écosse pas moins de $79,1 \%$ des infections importées chez les antillais, africains, autres nègres, asiatiques, et immigrants méditerranéens furent examinés aux dispensaires de port. Parmi les européens, irlandais et autres immigrants de race non nègre le pourcentage fut de $62,5 \%$, tandis que seulement $53,6 \%$ des natifs du Royaume-Uni fut examinés dans les dispensaires de marins.

(7) Il semble que les ports de mer restent la voie d'entrée majeure des infections syphilitiques. On a fait une liste de 8 dispensaires ( 5 appartenant à un port de mer, et 5 situés à Londres) ou $57,9 \%$ des infections importées ont été vues. Le plus grand port d'entrée fut le dispensaire de marins de Liverpool, avec 58 cas importés, mais 82 cas importés fut traités dans 5 dispensaires à Londres parmi lesquels il n'y eut que deux dispensaires de marins.

(8) Il n'y a pas de problème en ce qui concerne l'importation de la syphilis chez les femmes. En Angleterre et au pays de Galles on obtint des précisions sur l'origine de la syphilis dans 177 cas, et il n'y eut que 6 cas $(3,4 \%)$ d'infection importée. En Écosse les renseignements obtenus dans 30 cas sur 31 montrèrent que le syphilis ne fut importée en aucun cas. On n'a pas de renseignements sur le nombre de cas chez les femmes du à une syphilis importée chez les mâles. 